\title{
Collaborative strategy: Creating inclusive school-based guidance and counseling services
}

\author{
Sri Maullasari* \\ Guidance and Counseling, State University of Semarang, Semarang, Indonesia
}

\begin{abstract}
The purpose of this study was to describe collaborative strategies in creating inclusive school-based guidance and counseling services. Strengthening Inclusive Education required the role of all parties in educational institutions, including guidance and counseling. This study used the library research method. This literature study was related to the object of writing, which was inclusive guidance and counseling services. Every individual with special needs, both permanent and temporary, has different learning barriers and needs. School counselors were uniquely positioned to collaborate with stakeholders and identify each student's critical resources and support systems to achieve academic and socio-emotional success. Collaboration was the basis between the school and parents, and other experts to systematically, consistently, and sustainably.
\end{abstract}

\section{ARTICLE INFO}

\section{Keywords:}

Collaborative, guidance and counseling service, inclusive school

\section{Article History:}

Received: Dec 1st, 2021

Revised: Dec 20 th 2021

Accepted: Dec 21st, 2021

Published: Dec 30th, 2021

How to Cite in APA Style:

Maullasari, S. (2021).

Collaborative strategy:

Creating inclusive school-

based guidance and

counseling services.

Smaratungga: Journal of

Education and Buddhist

Studies, 1(2), 12-22. doi:

$10.53417 /$ sjebs.v1i2.56

\section{Introduction}

Guidance and counseling are a process of assistance provided by counselors to all students. In inclusive education, guidance and counseling activities are required to help students with special needs and regular students. According to the facts in the field, there are difficulties for counselors in implementing guidance and counseling programs in inclusive schools. The counselors find it hard to sort out programs implemented in guidance and counseling services in schools between students with disabilities and non-disabled students. The counselors also find it challenging to

${ }^{*}$ Corresponding author: maullasari174@students.unnes.ac.id
Published by Center of Research and Publication of Smaratungga Buddhist Collage

This is an open access article under the CC BY-NC 4.0 (https://creativecommons.org/licenses/by-nc/4.0/) https://doi.org/10.53417/sjebs.v1i2.56 
implement guidance and counseling programs to avoid differences and discrimination between disabled and non-disabled students later.

According to Ilahi (2013), inclusion is an educational service system that includes children with special needs studying together with their peers in regular schools close to where they live. Following this opinion, inclusive education combines the teaching and learning process between students with special needs and regular students in one class to study together. Myrick (2011) states that the developmental approach is an effort to identify specific skills and experiences students need as part of those who attend school and gain success.

Kustawan (2013) explains that guidance and counseling are programmed for children having obstacles or abnormalities in the education unit and must be based on and adapted to the particular needs of the children. To carry out guidance and counseling in inclusive schools, a counselor must adhere to the principle that each individual is unique and different, both physically and psychologically. Through this guidance and counseling for children with special needs, it should be a momentum for guidance and counseling to be involved in all aspects of existing education. This will become the spearhead for guidance and counseling to be more existent and show themselves the importance of guidance and counseling activities for children with special needs.

Guidance and counseling in inclusive schools are oriented towards developmental guidance and counseling. The concept of developmental guidance and counseling implies that the target of its services is not limited to regular students in an institutional setting but will be at all students in various life and cultural settings, including those with special needs. Guidance and counseling services make students with special needs subjects have unique personalities, both between individuals and their disabilities (Purwanta, 2012).

The author conducted a study on the "Collaborative Strategy; Creating Inclusion-Based Guidance and Counseling Services" based on the descriptions above. This is by looking at the importance of the collaborative element in implementing inclusive education in Indonesia. The collaborative services are interpreted as interactive, collaborative activities between Guidance and Counseling teachers or counselors with other parties.

\section{Method}

This study was carried out using a library research method, using library sources to obtain research data or limiting research activities to counseling guidance services (Chang, 2014). The steps taken in this study are: (1) identifying the position and role of the research being carried out in the context of the broader problem; (2) providing an interpretation of the results of the research studied; (3) using literature from other disciplines that provide implications for the research 
conducted; and (4) presenting the literature review results in a clear framework of thinking conceptual in a systematic way.

\section{Findings}

\section{Developmental problems of children with disabilities}

There must be directed care to achieve sound development. Care in the development through a learning process is often called education. According to their age or developmental phase, these developmental tasks relate to attitudes, behaviors, or skills that individuals should possess. Developmental tasks are social expectations. In achieving their developmental tasks, not a few have failed. Failure to achieve these developmental tasks will result in delinquency behavior or unhappy life situations. Behavioral deviations experienced by individuals are the impact of not completing developmental tasks, varying according to the phase of development (Yuliza, 2017).

Many children with disabilities get adverse treatment from their environment, even from their parents or family. This treatment takes the form of rejection, humiliation, neglect, and even torture so that their mental development becomes disrupted. The above conditions are strongly suspected to be experienced by individuals with special needs. The conditions they experience, such as having universal needs and special needs, relatively different from individuals in general in the context of self-development, make the environment hard or even unable to fulfill them. Therefore, they are ignored because they are considered troublesome or even embarrassing.

Every individual with special needs, both permanent and temporary, has different learning barriers and needs. Learning barriers experienced by each individual can be caused by three things, namely: (1) environmental factors, (2) factors within the individual himself, and (3) a combination of environmental factors and factors within the individual. Consequently, any given intervention, whether educational, psychological, media, or social, must be based on learning barriers and the needs of each individual. Therefore, every individual needs support, nurturing, guidance, and a good education from adults, especially parents and families. Not all individuals get these things from their environment (Kiswantoro, Lestari \& Zamroni, 2017).

Despite having limitations, groups of children with disabilities are not entirely dependent on others and cannot do anything for themselves or in social life (Farmawati, 2020). Disabilities or limitations experienced should not be a barrier for children with disabilities to get the right to live and defend their lives. Children with disabilities often have more abilities in other fields so they can work with all their limitations. Following the skills possessed, learning and training will enable children with disabilities to excel more than other normal children. Disability cannot 
be considered just a health problem. Disability is a complex phenomenon, reflecting the interaction of a person's body with the society in which he or she lives. Overcoming the difficulties experienced by children with disabilities means requiring interventions that can remove barriers to the environment and social life they face (Mubasyaroh, 2015).

\section{The meaning and purpose of inclusive education}

Based on Regulation of the Minister of National Education No. 70 of 2009, the definition of inclusive education is an education system that provides opportunities for students with disabilities and potential intelligence or unique talents to attend education with other students or in an educational environment to participate in learning education (Mendiknas, 2009). It is aplacement of children with mild, moderate, and severe disabilities in the classroom (Yuwono \& Utomo, 2021). This shows that regular classrooms are relevant learning facilities for children with disabilities, regardless of the type of disability. From this statement, it can be concluded that inclusive education is an educational offer for students with special needs without distinguishing between physical, intellectual, social, emotional, linguistic, or other conditions to offer educational offerings jointly.

\section{Inclusive Education}

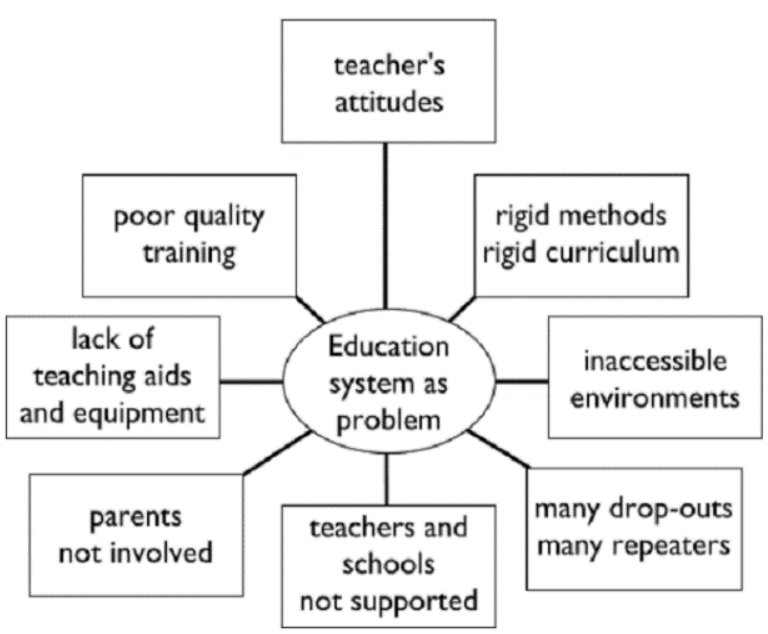

Figure 1. Inclusive Education ( Sharada \& Pramod in Hadi \& Laras, 2021)

Practical goals to be achieved through inclusive education include the immediate goals of children, teachers, parents, and the community. The goals of inclusive education are: (1) developing children's self-confidence, (2) increasing children's independence, and (3) increasing self-acceptance (Yuwono \& Utomo, 2021). Furthermore, inclusive education in Indonesia is held with a purpose: (1) provide the broadest possible opportunity for all children, including children with special needs, to get a proper education according to their needs; (2) helping 
accelerate the compulsory primary education program; (3) help improve the quality of primary and secondary education by reducing the number of class stays and dropouts; and (4) creating the mandate of the 1945 Constitution in particular article 31 paragraph 1, which reads 'every citizen has the right to education, and paragraph 2 which reads that every citizen is obliged to attend basic education and the government is obliged to pay for it. Law No. 20/2003 concerning the National Education System, in particular article 5 paragraph 1 which states that every citizen has the same rights to obtain quality education. 'Law No. 23/2002 on the protection of children, particularly article 51, which reads that children with physical and/or mental disabilities are given equal opportunities and accessibility to obtain ordinary and extraordinary education (Herawati, 2016). Therefore, based on the purposes mentioned above, it can be concluded that the purpose of inclusive education is to help children develop their potential at every stage of self-development tasks. The inclusive education is an education system for children with specific disabilities and other children articulated independently of their respective limitations (Garnida, 2015) This statement means that an education system must offer opportunities for everyone involved.

The Center for Studies on Inclusive Education (CSIE) in UK states that there are ten reasons for inclusive education, namely: (1) all children have something to learn together; (2) Children should not be discriminated against by separating them from other groups on the basis of their disability; (3) Prospective students with special educational needs who have passed segregation education demand an immediate end to the segregation system; (4) there is no valid reason to separate the education of children with disabilities because each has advantages and disadvantages; (5) Various studies show that the educational and social performance of children with special needs is better in integrated schools than in general schools; (6) no segregation education that cannot be implemented in public schools; (7) With exemplary commitment and support, inclusive education is more efficient in the use of learning resources; (8) the segregation system can cause a lot of prejudice and fear in children (uncomfortable); (9) all children need an education that helps them live in a normal society; 10) only an inclusive system has the potential to reduce fear and create a sense of friendship, mutual respect, and understanding (Hidayat \& Sunanto, J, 2015)

\section{Discussion}

\section{Implications of collaborative services in inclusive schools}

The provision of psychological services for students with special needs is carried out collaboratively by school psychologists, homeroom teachers, and counselors or guidance and counseling teachers. This collaboration is carried out with a teamteaching system for teaching and assessment. Counselors collaborate by conducting 
discussions and consultations with students and parents, discussions with school stakeholders, internal case meetings/conferences with schools, reconciliation and training of students with special needs, and identification and assessment for these students (Yuliawanti, 2019). Each school has journal records owned by students with special needs starting from the elementary level to the student's level.

In schools, cooperative guidance and support are necessary. It is because schools and teachers/counselors cannot function alone to meet all student needs. The expected school counselor in the present and the future is a school counselor who can develop and design programs that involve parents in the education of their children through collaborative activities (Comfort, 2020). The comprehensive guidance and counseling program includes joint activities related to students' academic, professional, and personal/social development. Collaborative activities are carried out with schoolmates, parents, and colleagues from the wider community (Dollarhide, 2012). The current broad paradigm with merit-oriented counseling is to help students complete developmental tasks and overcome obstacles they face.

There are some characteristics of collaborative implementation in counseling, which are: (1) participation is not limited or hierarchical; (2) responsible participation to ensure success; (3) the existence of a reasonable goal; (4) there is a problem definition; (5) mutual participation in joint education or teaching; (7) identify and examine different options; (7) solution implementation is divided into several parties involved; and (8) participation is always aware of the development of the situation (Young et al., 2013). This is important because, without trust, cooperation is impossible, assertiveness is a threat, efforts to avoid responsibility occur, and communication breakdowns occur.

The expansion of educational programs, such as inclusive schools, provides students with special needs opportunities to achieve the highest possible level of education according to their abilities. This direction raises the need for guidance, namely in choosing the most appropriate continuation school for children with special needs and assessing the ability concerned about whether it is possible to continue their education to a higher level. This condition requires guidance or counseling to deal with it systematically. Therefore, it can be concluded that the role of the supervising teacher or counselor is necessary for helping students with special needs through guidance and counseling services. In providing services, of course, the counselor or supervising teacher has program plans to be implemented, and the content of the guidance and counseling program also needs to be adjusted to the school's goals (Darminto \& Dewanty, 2013).

Furthermore, guidance and counseling in inclusive education is an integrative development approach that aims to meet the learning needs of all children without distinction and separation (Witono, 2020). In other words, inclusive education seeks to give equal rights to all students to develop their 
potential. All students with physical, emotional, psychological, and social disabilities or special needs have a right to participate in inclusive education in specific academic units according to their needs and abilities. The aspects revealed in this study are part of the professional competence of counseling guidance teachers, namely, (1) the method used by the counseling guidance teacher in identifying students with special needs/needs assessment, (2) program development carried out to develop the potential of students with special needs, and (3) implementation of guidance and counseling programs/services for students with special needs.

\section{Collaborative strategy in creating inclusive school-based guidance and counseling services}

Collaboration is the process of two individuals or groups working together for a common goal and benefiting each other by pursuing a desired outcome. Collaboration is to build an interdependent system to achieve common goals that cannot be achieved if done alone (Liddarsyah \& Helen, 2020). The American School Counselor Association (ASCA, 2019) underlines the collaborative role in the National Model, which says that school counselors build effective teams by encouraging genuine collaboration among all school staff to work toward the common goal of equity, access, and academic success of every student. Regarding collaboration in guidance and counseling, research conducted by Bryan (Young et al., 2013) shows that collaboration between counselors and different parties, including parents, impacts the high level of student motivation. Collaborative activities with parental participation in children's education can increase and increase the potential for success, greater motivation, attendance, discipline, better task performance, and the possibility of completing training on time (Bryan et al., 2019).

Quality students are only formed through quality education. A quality education process is needed to achieve quality educational outcomes (Thareja, 2019). The abilities concern not only academic aspects but also involve various comprehensive aspects of life. They are personal development, social development, individual maturity, and value systems. Education today demands collaboration with parties in various educational activities. Special education teachers and regular classroom teachers can change the trend of overrepresented groups in special education. Although some students need special education, school counselors have a responsibility to help teachers implement interventions that are less stringent than special education (Stone \& Dahir, 2015).

The implementation of inclusive education in traditional schools must be supported by several substantial elements so that its implementation can develop optimally. The three elements include a) participation of all students, b) the same place to study, and c) services tailored to the needs of students (Hidayat \& Sunanto, $\mathrm{J}, 2015)$. This then raises the question of the willingness of formal schools to 
implement inclusive education in their learning system. The results of Mumpuniarti \& Lestari (2019) show the willingness of schools to implement an inclusive education system in schools, 100\% in kindergarten, 85.7 in elementary school, and $88.5 \%$ in high school. This result means that most schools are ready to accept the diversity of students in the classroom.

Counselors and parties involved in collaboration should understand the characteristics of collaboration. Therefore, it enables the collaborating parties to participate optimally according to their respective duties, roles, and responsibilities. Guidance and outreach counseling services can only be achieved if school management and leadership support a professional collaboration between teachers and the implementation of services (Nugraha \& Rahman, 2017). An effective program requires the cooperation and active participation of all school staff. Schools across the country are regulated differently. Job titles and duties vary from school to school, and some schools have more employees and resources than others. The comprehensive developmental guidance program is built mainly on the work of (1) administrators, (2) teachers, (3) counselors, and (4) other support personnel (Purakom \& Soykeree, 2017).

There are several models used in collaborative guidance. The first is policy groups, both local to certain areas and national, consisting of professionals and parents who aim to solve a particular problem. The second is Parent-faculty partnership programs, training programs for prospective teachers to collaborate with professionals and parents who have specific disabilities. The third is cotraining, which is exceptional education professionals and parents can participate in schools or other institutions by providing training, communication, collaboration, positive behavioral interventions, or other things for school staff and other parents. The fourth is a material review, which is parents (both individuals and groups) can review the material developed by professionals, aiming that the material can meet the needs of parents who take part in the training particular. The fifth is parents as trainers, where parents can train school staff in various strategies to increase the involvement of other parents. The sixth is professionals as trainers, where professionals can discuss with parent groups practical ways to increase their involvement in education and support the development of their children. The last one is the parent training and information centers/community parent resource center model, an institution that provides information and training aimed at helping parents (Chodijah, 2017).Another advantage for parents is being able to connect with other parents who have the same problem. Meanwhile, this activity can provide information about what parents need and think about these activities for professionals.

School counselors are in a unique position. They need to collaborate with stakeholders and identify each student's critical resources and support systems to achieve academic achievement and socio-emotional development (Stone \& Dahir, 
2015). Some students need additional tools, time, and special instruction to achieve minimum proficiency. Special education covers the entire range of learning, emotional, and physical disabilities, and in some states also includes students with abilities, talents, or unique talents. Teachers also cannot do everything alone. Therefore, it is necessary to involve parents, so implementing activities at school is sustainable with student activities at home. Thus, it takes a collaborative role of counselors, development of counselor skills, and implementation of professional counseling guidance programs to optimize the development of students with special needs in inclusive schools. Collaboration for student success is an integral part of educational reform in inclusive schools.

\section{Conclusion}

Guidance and counseling services in inclusive schools should be oriented towards developmental guidance and counseling by the target of services, not only to regular students in an institutional setting but also to all students in various life and cultural settings, including students with special needs. Counselors and parties involved in collaboration should clearly understand collaboration characteristics to participate optimally, following their respective duties, roles, and responsibilities.

\section{References}

American School Counselor Association (2012). The ASCA National Model: A Framework for School Counseling Programs, Third Edition. Alexandria, VA: Author.

Bryan, J., Griffin, D., Kim, J., Griffin, D. M., \& Young, A. (2019). School counselor leadership in school-family-community partnerships: An equity-focused partnership process model for moving the field forward. The Wiley Handbook of Family, School, and Community Relationships in Education $1^{\text {st }}$ Edition, 265287. doi: $10.1002 / 9781119083054 . c h 13$

Chang, W. (2014). Metodologi Penulisan Ilmiah. Jakarta: Penerbit Erlangga.

Chodijah, M. (2017). Urgensi bimbingan kolaboratif bagi anak yang mengalami learning disabilities di sekolah dasar. Syifa Al-Qulub, 1(2), 31-41. doi: 10.15575/saq.v1i2.1430

Comfort, A. (2020). Counselling as a Learning Function with Emphasis on Personality of the Counsellor. The International Journal of Community and Social Development, 7(4), 33-42.

Dollarhide, C. T. (2012). Comprehensive School Counseling Programs. New Jersey: Pearson Education Inc.

Darminto, D. E., \& Dewanty, C., S . (2013). Guidance and counseling program model at junior high school inclusive education providers. Jurnal Bimbingan dan Konseling, 1(1), 44-49.

Farmawati, Cintami. (2020). Being a good multicultural counselor for persons with disabilities. Jurna IKonseling Religi, 11(1),1-17. doi: 10.21043/kr.v11i1

Garnida. (2015). Pengantar Pendidikan Inklusif. Bandung: PT. Refika Aditama.

Hadi, A., \& Laras, P. P. B. (2021). Peran guru bimbingan dan konseling dalam pendidikan inklusi. Selaras: Kajian Bimbingan Dan Konseling serta Psikologi 
Pendidikan, 2(1), 17-24. doi: 10.33541/Jsvol2iss1pp1

Herawati, N., I. (2016). Pendidikan inklusif. Jurnal Pendidikan Dasar Kampus Cibiru, 2(1). doi: 10.17509/eh.v2i1.2755

Hidayat \& Sunanto, J. (2015). Pendidikan Inklusif di Kota Bandung. Bandung: Bidang P3TK Dinas Pendidikan Kota Bandung.

Kiswantoro, A., Lestari, I., Zamroni, E. (2017). Konseling bagi konseli berkebutuhan khusus. Proceeding Seminar Dan Lokakarya Nasional Revitalisasi Laboratorium Dan Jurnal Ilmiah Dalam Implementasi Kurikulum Bimbingan Dan Konseling Berbasis KKNI, 4-6. Retreived from : http://journal2.um.ac.id/index.php/sembk/article/view/1476

Liddarsyah, L., \& Helen, J. Van. (2020). Guidance and counseling services for inclusion schools. Indonesian Journal of Creative Counseling, 1(1), 1-7. doi: 10.47679/ijcc.v1i1.25

Mendiknas. (2009). Peraturan Menter Pendidikan Nasional Republik Indonesia No. 70 Tahun 2009 tentang Pendidikan Inklusif Bagi Peserta Didik yang Memiliki Kelainan dan Memiliki Potensi Kecerdasan dan/atau Bakat Istimewa. Retreived from http://pdpt.unimus.ac.id/2012/wpcontent/uploads/2012/05/Permen-No.-70-2009- tentang-pendidiianinklusif-memiliki-kelainan-kecerdasan.pdf

Mubasyaroh. (2015). Pendidikan bagi penyandang disabilitas dan anak berkesulitan belajar; analisis penanganan berbasis bimbingan konseling Islam. Jurnal Elementary, 3(2), 254-272. doi: $10.21043 /$ elementary.v3i2.1453

Mumpuniarti, M., \& Lestari, P. H. K. (2019). Kesiapan guru sekolah reguler untuk implentasi pendidikan inklusif. JPK (Jurnal Pendidikan Khusus), 14(2), 57-61. doi: $10.21831 /$ jpk.v14i2.25167

Nugraha, A., \& Rahman, F. A. (2017). Strategi kolaborasi orangtua dengan konselor dalam mengembangkan sukses studi siswa. Jurnal Konseling GUSJIGANG, 3(1), 128-136.

Purakom, A., \& Soykeree, T. (2017). Stem education: innovation education for young generation in Asean. Proceedings Education and Language International Conference, $\quad$ Semarang, 1(1), 9-12. http://jurnal.unissula.ac.id/index.php/ELIC/article/view/1206

Purwanta, E. (2012). Upaya meningkatan eksplorasi karier anak berkebutuhan khusus. PSIKOPEDAGOGIA Jurnal Bimbingan Dan Konseling, 1(2). doi: 10.12928/psikopedagogia.v1i2.2462

Stone, C. B., \& Dahir, C. A. (2010). The Transformed School Counselor. In Encyclopedia of Cross-Cultural School Psychology.

Thareja P. The educaton of quality for quality educaton. J Adv Res Eng \& Edu 2017, 2(2): 16-30.

Witono, A. H. (2020). Peran bimbingan dan konseling dalam penyelenggaraan pendidikan inklusif. Progres Pendidikan, 1(3), 154-167. doi: 10.29303/prospek.v1i3.20

Yuliawanti, R. (2019). Peran kolaboratif konselor di sekolah. Jurnal Ideguru, 4(1), 68-74.

Yuliza, E. (2017). Upaya bimbingan konseling dalam pengembangan karakter siswa. AL-ISHLAH: Jurnal Pendidikan, 9(1). 14-32. doi: 10.35445/alishlah.v9i1.2 
Young, A. A., Millard, T., \& Kneale, M. M. (2013). Enhancing school counselor instructional leadership through collaborative teaming: implications for principals. NASSP Bulletin, 97(3), 253-269. doi:10.1177/0192636513483356

Yuwono, P. \& Utomo, H. (2021). Pendidikan Inklusi. Yogyakarta: Deepublish Publisher. 